62

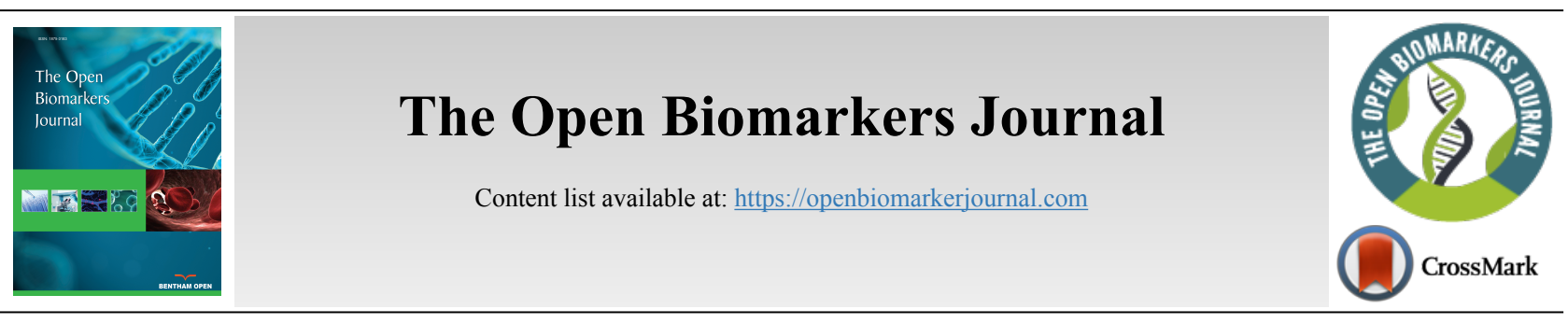

RESEARCH ARTICLE

\title{
Protective Efficacy of Vitamin F against Acrylamide Induced Toxicity: Studies on Oxidative Stress Biomarkers
}

\author{
Sadhana Shrivastava ${ }^{1, *}$, Satendra K. Nirala ${ }^{2}$, Mohammad S. Reshi ${ }^{1}$, Sangeeta Shukla ${ }^{1}$, Anjali Sharma ${ }^{1}$ and Chhavi Uthra ${ }^{1}$ \\ ${ }^{\prime}$ UNESCO Satellite Centre for Trace Element Research UGC-SAP School of Studies in Zoology, Jiwaji University, Gwalior (M.P.) India \\ ${ }^{2}$ Department of Rural Technology and Social Development Guru Ghasidas (Central) University, Bilaspur (C.G.), India
}

\begin{abstract}
:
Introduction:

Vitamin F is also known as Linoleic Acid (LA), is an Essential Fatty Acid (EFA) which is not produced in humans. It can be modified to form essential precursors such as arachidonic acid which is used to make prostaglandins, thromboxanes, and leukotrienes. It is found in abundance in several vegetable oils such as sunflower, poppy seed, safflower and corn oils. LA has shown diverse beneficial effects against diseases such as cancer, skin permeability, insulin resistance, depression and cardiovascular diseases. Acrylamide (AA) is a well known neurotoxic, carcinogenic and genotoxic compound. It is used universally in the industrial process and recently found in various food products which are cooked at a temperature above $120^{\circ} \mathrm{C}$ such as potato crisps, bread, cookies and french fries. Over exposure of humans and laboratory animals to monomer AA causes damages to the central and peripheral nervous system.

Objective:

To investigate the therapeutic effect of linoleic acid against acrylamide toxicity.

Methods:

AA was given at $38.27 \mathrm{mg} / \mathrm{kg}$ dose for 10 days and therapy with different doses of linoleic acid for three days (11-13 days) to female albino rats.

Results:

Signs and symptoms of acrylamide toxicity occur, they include significant body weight reduction, hair loss, splaying of hindlimbs, dragging of back legs and skin irritation. A significant decline was observed in hemoglobin level and GSH, whereas significant enhancement in LPO was noted, as compared to the control group after AA exposure. The activity of acetylcholinesterase was decreased in the brain after AA administration. AA significantly reduced the superoxide dismutase and catalase activities in liver, kidney and brain but activities of serum transaminases, bilirubin, creatinine, urea and lipid profile increased in serum. Biochemical studies were also strengthened by histopathological observations.

Conclusion:

Study has shown that linoleic acid promotes defense against AA toxicity.
\end{abstract}

Keywords: Acrylamide, Brain, Essential fatty acid, Kidney, Liver, Linoleic Acid.

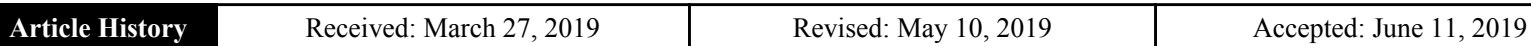

\section{INTRODUCTION}

Nowadays, there is an increased interest in the function and medicinal properties of specific dietary fatty acids. Linoleic Acid (LA) is a metabolic precursor for arachidonic acid synthesis and essential fatty acids in the human diet $[1,2]$. It

\footnotetext{
* Address correspondence to this author at UNESCO Satellite Centre for Trace Element Research UGC-SAP, School of Studies in Zoology, Jiwaji University, Gwalior (M.P.), India; E-mail: dr_sadhana59@rediffmail.com
}

plays a vital role in the function of the brain, normal growth, regeneration of skin and hair, bone health and metabolic function. Sources of LA are sunflower, safflower, soybean, corn, evening primrose and canola oil.

The potential health-related benefits of polyunsaturated fatty acids are antimalarial, antimycobacterial, antiatherogenic, antidiabetogenic, anti-inflammatory, antidepressant, antifungal, neuroprotective in diabetic human and immune modulating properties [3 - 6]. LA shows the antioxidant effects of natural 
phenols which inhibit cholesterol and fatty acid biosynthesis pathway [1]. LA is an essential omega-6 polyunsaturated fatty acid with 18-carbon chain with two sites of unsaturation (Fig. 1).

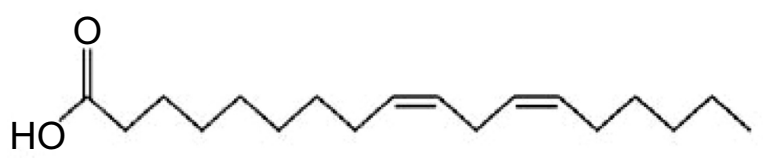

Fig. (1). Structure of Linoleic acid.

Acrylamide (AA) is a vinyl monomer having high watersolubility. It is used in the manufacturing polyacrylamides, in cosmetic industries such as lotions, cosmetics, deodorants [7]. Recently, it was detected in certain food products which raises a worldwide concern because nowadays every individual exposed to AA contained food products such as coffee, cookies, bread, potato crisps $[8,9]$. AA is produced when carbohydrate-rich foods are processed at high temperature (higher than $120^{\circ} \mathrm{C}$ ) during baking, grilling or frying [10]. It is carcinogenic, nephrotoxic, neurotoxic and induces reproductive toxicity exposure in mice and rats $[11,12]$. Children eat more AA containing food than adults because they consume high AA rich diet and high calories relative to body weight [13]. AA is known as a potent neurotoxic agent damaged the peripheral and central nervous system. The neurotoxic effect includes muscle weakness, paraesthesia, foot drop, the absence of tendon reflex, neurotrauma and muscular atrophy due to oxidative stress [14]. Recently, growing evidence on the therapeutic efficacy of Linoleic Acid (LA), this study investigates its protective effect against AA toxicity.

\section{MATERIALS AND METHODS}

\subsection{Experimental Animals}

Female albino rats of Wistar strain $(160 \pm 10 \mathrm{~g}$ body wt) were used in this study. Animals were housed under standard husbandry conditions $\left(25 \pm 2^{\circ} \mathrm{C}\right.$ temp, $60-70 \%$ relative humidity and $12 \mathrm{~h}$ photoperiod) and had access to standard rat feed and drinking water ad libitum. Animals were treated and cared in accordance with the guidelines recommended by the Committee for the Purpose of Control and Supervision of Experiments on Animals (CPCSEA)

\subsection{Chemicals}

Acrylamide and linoleic acid were purchased from Sigma Aldrich. All other chemicals and reagents were procured from Ranbaxy, New Delhi and Himedia Laboratories Ltd. Mumbai, India and are of analytical grade. All diagnostic kits were procured from E-Merck, autoanalyzer (Micro Lab 200, Merck) was used for the measurements.

\subsection{Experimental Design}

Group I: Control

Group II:Linoleic acid, $40 \mathrm{mg} / \mathrm{kg}$ orally (03 days)

Group III:AA at $38.27 \mathrm{mg} / \mathrm{kg}$, p.o. $\left(1 / 3^{\text {rd }}\right.$ of $\left.\mathrm{LD}_{50}\right)$ for 10 days, 11-13days Rest
Group IV:AA (As Group III)+Linoleic acid, $05 \mathrm{mg} / \mathrm{kg}$ orally (03 days)

Group V:AA (As Group III)+Linoleic acid, $10 \mathrm{mg} / \mathrm{kg}$ orally (03 days)

Group VI:AA (As Group III)+Linoleic acid, $20 \mathrm{mg} / \mathrm{kg}$ orally (03 days)

Group VII:AA (As Group III)+Linoleic acid, $40 \mathrm{mg} / \mathrm{kg}$ orally (03 days) (Fig. 2)

All animals were sacrificed after $24 \mathrm{~h}$ of last treatment.

\subsection{Biochemical Assays}

Blood was collected from retro-orbital venous sinus and was allowed to stand at room temperature for $30 \mathrm{~min}$ and serum was harvested by centrifugation at $2000 \mathrm{rpm}$ for $15 \mathrm{~min}$ [15]. Serum was used for the determination of aspartate aminotransaminases and alanine aminotransaminases [16]. Autoanalyser was used to determine the concentration of Triglyceride (TG), cholesterol, creatinine,albumin and urea in serum (kit method). Brain Acetylcholinesterase (AChE) activity was also assessed [17]. Levels of LPO [18], GSH [19], Catalase [20] and Superoxide dismutase [21] were estimated in liver, kidney and brain.

\subsection{Histopathology}

Immediately after necropsy, hepatic, renal and cerebral tissues were excised out and washed in normal saline and immediately fixed in Bouin's fixative. Paraffin sections were routinely prepared at $5 \mu \mathrm{m}$ thickness. Hematoxylin and Eosin (H\&E) staining was done and stained slides were observed under a light microscope.

\subsection{Statistical Analysis}

The Standard Deviation (SD) measures the amount of variability or dispersion for a subject set of data from the mean whereas, Standard Error of Mean (SEM) measures how far the sample mean of the data is likely to be from the true population. Thus, SEM is more appropriate for data of small sample size and the results have been presented as Mean \pm SEM. Further, significant between two groups were measured by Student's t test [22] followed by ANOVA instead of hypothetical probability value.

\section{RESULTS}

\subsection{Biochemical Results}

Tables 1-3 depicts that there was significant $(\mathrm{P} \leq 0.05)$ elevation in the serum transaminases (AST and ALT) activity and bilirubin, whereas depletion in the haemoglobin percentage after AA administration. Therapy with LAat $5,10,20,40 \mathrm{mg} / \mathrm{Kg}$ doses restored the levels of serum transaminases, haemoglobin percentage, bilirubin and albumin (Tables $1 \& 3$ ). The toxic effect of AA was significantly attenuated by treatment with LA at $20,40 \mathrm{mg} / \mathrm{Kg}$ compared with $5,10 \mathrm{mg} / \mathrm{Kg}$ dose $(\mathrm{p} \leq 0.05)$.

Table 2 demonstrated that AA intoxication caused a significant $(\mathrm{P} \leq 0.05)$ elevation in serum lipid profile such as triglycerides, cholesterol. Also, exposure to AA caused a 
significant increase in the concentration of urea, creatinine in serum $(\mathrm{P} \leq 0.05)$ as compared to the control group due to kidney dysfunctions. Therapy with LA at $5,10,20,40 \mathrm{mg} / \mathrm{Kg}$ doses prevented all the parameters and recovered in a statistically significant manner (Table 2).

Acetylcholinesterase (AChE) activity in rat brain was evaluated, and the results are shown in Table 3. Brain acetylcholinesterase (AChE) activities were significantly inhibited $(\mathrm{P} \leq 0.05)$ after AA exposure. When treated with LA at different dose levels $(5,10,20,40 \mathrm{mg} / \mathrm{Kg})$ significantly ameliorated the activity of $\mathrm{AChE}(\mathrm{P} \leq 0.05)$ (Table 3$)$.

The alterations in the level of TBARS and GSH are shown in Table 4. The production of TBARS increased in liver, kidney and brain tissues with AA exposure $(\mathrm{P} \leq 0.05)$, whereas GSH levels were significantly $(\mathrm{P} \leq 0.05)$ decreased in AA group as compared to control and LA per se groups. Treatment with therapeutic agent $\mathrm{LA}(5,10,20,40 \mathrm{mg} / \mathrm{Kg})$ significantly decrease the formation of TBARS and enhanced the GSH contents in all tissues $(\mathrm{P} \leq 0.05)$.

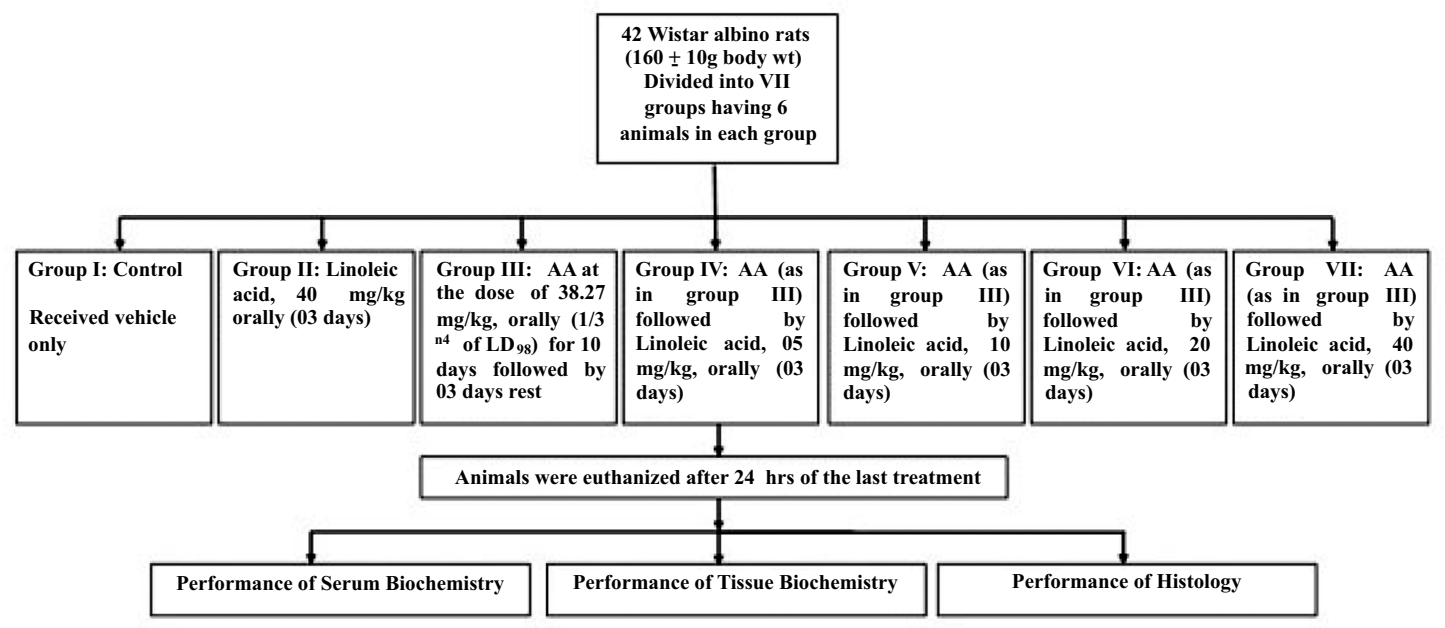

Fig. (2). Experimental Design.

Table 1. Influence of vitamin $\mathrm{F}$ against $\mathrm{AA}$ induced toxicity on liver function tests and $\mathrm{Hb} \%$ in rats.

\begin{tabular}{|c|c|c|c|c|}
\hline Treatments & $\begin{array}{c}\text { AST } \\
(\mathbf{I U} / \mathbf{L}) \\
\end{array}$ & $\begin{array}{c}\text { ALT } \\
\text { (IU /L) }\end{array}$ & $\begin{array}{c}\text { Albumin } \\
\text { (mg/dl) }\end{array}$ & $\begin{array}{c}\text { Haemoglobin } \\
(\%)\end{array}$ \\
\hline $\begin{array}{c}\text { Control } \\
\text { Per se } \mathrm{LA}_{40} \\
\text { AA } \\
\mathrm{AA}+\mathrm{LA}_{5} \\
\mathrm{AA}+\mathrm{LA}_{10} \\
\mathrm{AA}+\mathrm{LA}_{20} \\
\mathrm{AA}+\mathrm{LA}_{40} \\
\end{array}$ & $\begin{array}{c}58.00 \pm 3.20 \\
62.00 \pm 3.42 \\
132.5 \pm 7.32^{\#} \\
122.2 \pm 6.75 \\
117.6 \pm 6.50 \\
106.0 \pm 5.85^{*} \\
113.0 \pm 6.27^{*}\end{array}$ & $\begin{array}{c}37.38 \pm 2.06 \\
43.38 \pm 2.39 \\
170.0 \pm 9.39^{\#} \\
78.01 \pm 4.31^{*} \\
69.52 \pm 3.84^{*} \\
53.64 \pm 2.96^{*} \\
53.65 \pm 2.96^{*}\end{array}$ & $\begin{array}{c}3.10 \pm 0.17 \\
3.00 \pm 0.16 \\
4.42 \pm 0.23^{\#} \\
3.90 \pm 0.21 \\
3.80 \pm 0.21 \\
3.50 \pm 0.19^{*} \\
3.40 \pm 0.18^{*}\end{array}$ & $\begin{array}{l}15.80 \pm 0.87 \\
13.40 \pm 0.74 \\
9.300 \pm 0.51^{\#} \\
11.70 \pm 0.64^{*} \\
13.07 \pm 0.72^{*} \\
13.26 \pm 0.73^{*} \\
12.92 \pm 0.71^{*}\end{array}$ \\
\hline Anova (F Value) & $31.10^{@}$ & $115.7^{(a)}$ & $5.897^{\circledR}$ & $9.203^{@}$ \\
\hline
\end{tabular}

Values are mean \pm S.E., $\mathrm{N}=6$. $\# \mathrm{P} \leq 0.05$ vs control group, ${ }^{*} \mathrm{P} \leq 0.05$ vs AA administered group.

ANOVA (F values) ${ }^{\varrho}=$ Significant, ${ }^{\mathrm{ns}}=$ Non significant at $5 \%$ level.

Table 2. Influence of vitamin F against AA induced toxicity on lipid profile and kidney function markers of rats.

\begin{tabular}{|c|c|c|c|}
\hline Treatments & $\begin{array}{c}\text { Triglycerides } \\
(\mathbf{m g} / \mathbf{d l})\end{array}$ & Creatinine (mg/dl) & Cholesterol (mg/d) \\
$(\mathbf{m g} / \mathbf{d l})$
\end{tabular}

Values are mean \pm S.E., $\mathrm{N}=6$. $\# \mathrm{P} \leq 0.05$ vs control group, $* \mathrm{P} \leq 0.05$ vs AA administered group.

ANOVA (F values) ${ }^{\varrho}=$ Significant, ${ }^{\text {ns }}=$ Non significant at $5 \%$ level. 
Table 3. Influence of vitamin F against AA induced toxicity on acetyl cholinesterase activity.

\begin{tabular}{|c|c|c|c|c|}
\hline & \multicolumn{2}{|c|}{ Acetyl Cholinesterase ( $\boldsymbol{\mu}$ mole / min / mg protein) } \\
\hline Treatments & Fore Brain & Mid Brain & Hind Brain \\
(mg/dl)
\end{tabular}

Values are mean \pm S.E., $\mathrm{N}=6$. $\# \mathrm{P} \leq 0.05 v s$ control group, $* \mathrm{P} \leq 0.05 v \mathrm{~s}$ AA administered group.

ANOVA $\left(\mathrm{F}\right.$ values ${ }^{@}{ }^{@}=$ Significant, ${ }^{\mathrm{ns}}=$ Non significant at $5 \%$ level.

Table 4. Influence of vitamin $F$ against $A A$ induced toxicity on lipid peroxidation and reduced glutathione of rats.

\begin{tabular}{|c|c|c|c|c|c|c|}
\hline \multirow[b]{2}{*}{ Treatments } & \multicolumn{3}{|c|}{$\begin{array}{c}\text { Lipid Peroxidation } \\
\text { (n mole MDA / mg Protein) }\end{array}$} & \multicolumn{3}{|c|}{$\begin{array}{l}\text { Glutathione } \\
(\mu \text { mole / g) }\end{array}$} \\
\hline & Liver & Kidney & Brain & Liver & Kidney & Brain \\
\hline Control & $0.22 \pm 0.01$ & $0.33 \pm 0.01$ & $0.35 \pm 0.01$ & $8.30 \pm 0.45$ & $8.17 \pm 0.45$ & $7.96 \pm 0.44$ \\
\hline $\mathrm{AA}+\mathrm{LA}_{40}$ & $0.23 \pm 0.01$ & $0.46 \pm 0.02$ & $0.55 \pm 0.03$ & $7.80 \pm 0.43$ & $7.93 \pm 0.43$ & $7.65 \pm 0.42$ \\
\hline AA & $1.29 \pm 0.07^{\#}$ & $2.15 \pm 0.11^{\#}$ & $2.21 \pm 0.12^{\#}$ & $5.70 \pm 0.31^{\#}$ & $6.20 \pm 0.34^{\#}$ & $5.50 \pm 0.30^{\#}$ \\
\hline $\mathrm{AA}+\mathrm{LA}_{5}$ & $0.88 \pm 0.04^{*}$ & $2.03 \pm 0.11$ & $1.52 \pm 0.08^{*}$ & $7.22 \pm 0.39^{*}$ & $7.20 \pm 0.39$ & $7.44 \pm 0.41 *$ \\
\hline $\mathrm{AA}+\mathrm{LA}_{10}$ & $0.59 \pm 0.03 *$ & $1.80 \pm 0.09 *$ & $1.03 \pm 0.05^{*}$ & $7.68 \pm 0.42 *$ & $7.46 \pm 0.41 *$ & $7.56 \pm 0.41 *$ \\
\hline $\mathrm{AA}+\mathrm{LA}_{20}$ & $0.55 \pm 0.03 *$ & $1.74 \pm 0.09 *$ & $0.95 \pm 0.05^{*}$ & $7.72 \pm 0.42 *$ & $7.81 \pm 0.43 *$ & $7.59 \pm 0.41 *$ \\
\hline Per seLA ${ }_{40}$ & $0.68 \pm 0.03 *$ & $1.70 \pm 0.09 *$ & $0.80 \pm 0.04 *$ & $7.80 \pm 0.43^{*}$ & $8.06 \pm 0.44^{*}$ & $7.46 \pm 0.41 *$ \\
\hline Anova (F Value) & $105.8^{@}$ & $83.98^{@}$ & $105.9^{@}$ & $4.913^{@}$ & $3.200^{@}$ & $4.840^{@}$ \\
\hline
\end{tabular}

Values are mean \pm S.E., $\mathrm{N}=6$. $\# \mathrm{P} \leq 0.05 v s$ control group, $* \mathrm{P} \leq 0.05$ vs AA administered group.

ANOVA $\left(\mathrm{F}\right.$ values) ${ }^{\circledR}=$ Significant, ${ }^{\mathrm{ns}}=$ Non significant at $5 \%$ level.

Table 5. Influence of vitamin F against AA induced toxicity on oxidative stress markers in rats.

\begin{tabular}{|c|c|c|c|c|c|c|}
\hline \multirow[b]{2}{*}{ Treatments } & \multicolumn{3}{|c|}{$\begin{array}{l}\text { Superoxide Dismutase } \\
(\mu / \mathrm{min} / \mathrm{mg} \text { Protein })\end{array}$} & \multicolumn{3}{|c|}{$\begin{array}{c}\text { Catalase } \\
(\mu \mathrm{mol} \mathrm{H2O2} / \mathrm{min} / \mathrm{mg} \text { Protein) }\end{array}$} \\
\hline & Liver & Kidney & Brain & Liver & Kidney & Brain \\
\hline Control & $66.00 \pm 3.64$ & $63.00 \pm 3.48$ & $58.00 \pm 3.20$ & $63.00 \pm 3.48$ & $70.40 \pm 3.89$ & $77.00 \pm 4.25$ \\
\hline Perse $\mathrm{LA}_{40}$ & $64.47 \pm 3.56$ & $65.67 \pm 3.63$ & $56.00 \pm 3.09$ & $58.55 \pm 3.23$ & $66.73 \pm 3.68$ & $68.70 \pm 3.79$ \\
\hline AA & $30.60 \pm 1.69^{\#}$ & $31.00 \pm 1.71^{\#}$ & $36.00 \pm 1.99^{\#}$ & $33.00 \pm 1.82^{\#}$ & $44.00 \pm 2.43^{\#}$ & $45.00 \pm 2.48^{\#}$ \\
\hline $\mathrm{AA}+\mathrm{LA}_{5}$ & $49.42 \pm 2.73^{*}$ & $46.62 \pm 2.57^{*}$ & $46.90 \pm 2.59 *$ & $38.00 \pm 2.10$ & $55.60 \pm 3.07 *$ & $56.79 \pm 3.13^{*}$ \\
\hline $\mathrm{AA}+\mathrm{LA}_{10}$ & $56.37 \pm 3.11 *$ & $52.28 \pm 2.89^{*}$ & $47.44 \pm 2.62 *$ & $40.00 \pm 2.21^{*}$ & $56.00 \pm 3.09 *$ & $58.00 \pm 3.20^{*}$ \\
\hline $\mathrm{AA}+\mathrm{LA}_{20}$ & $62.31 \pm 3.44 *$ & $62.98 \pm 3.48^{*}$ & $49.22 \pm 2.72 *$ & $44.03 \pm 3.43^{*}$ & $60.00 \pm 3.31 *$ & $62.00 \pm 3.42 *$ \\
\hline $\mathrm{AA}+\mathrm{LA}_{40}$ & $61.26 \pm 3.38 *$ & $64.64 \pm 3.57^{*}$ & $54.17 \pm 2.99 *$ & $45.63 \pm 3.52 *$ & $62.09 \pm 3.43^{*}$ & $64.00 \pm 3.53^{*}$ \\
\hline Anova (F Value) & $18.89^{@}$ & $20.63^{@}$ & $8.576^{@}$ & $21.20^{@}$ & $8.152^{@}$ & $10.19^{@}$ \\
\hline
\end{tabular}

Values are mean \pm S.E., $\mathrm{N}=6$. $\# \mathrm{P} \leq 0.05$ vs control group, $* \mathrm{P} \leq 0.05$ vs AA administered group.

ANOVA (F values) ${ }^{\circledR}=$ Significant, ${ }^{\text {ns }}=$ Non significant at $5 \%$ level.

Table 5 shows the hepatic, renal and cerebral SOD and CAT activities. Compared with the control group, administration of AA alone significantly declined the SOD and CAT activity $(\mathrm{P} \leq 0.05)$. Therapy with $\mathrm{LA}(5,10,20,40 \mathrm{mg} / \mathrm{Kg})$, SOD and CAT activity was effectively restored in all the organs (Table 5).

Data of this study showed no significant difference between the activity of ALT, AST, SOD, CAT, AchE as well as the levels of bilirubin, urea, creatinine, GSH, TBARS of the control group and LA per se $(40 \mathrm{mg} / \mathrm{kg})$ group. These results suggest that $20 \mathrm{mg} / \mathrm{kg}$ dose of LA is the effective dose for preventing AA-induced oxidative stress in rats.

\subsection{Histological Results}

Liver of control rat shows the normal central vein, portal area and sinusoidal spaces with the surrounding hepatocytes. Following 10 days of AA administration, disruption in the hepatic cord, Kupffer cells proliferation, heterochromatic nuclei, were detected in between the hypertrophied and vacuolated cytoplasm of hepatocyte (Fig. 3). Therapy with the LA group showed improvement in hepatic cords with maintained Kupffer cells, nuclei, the central vein with almost hexagonal hepatocytes (Fig. 4). 


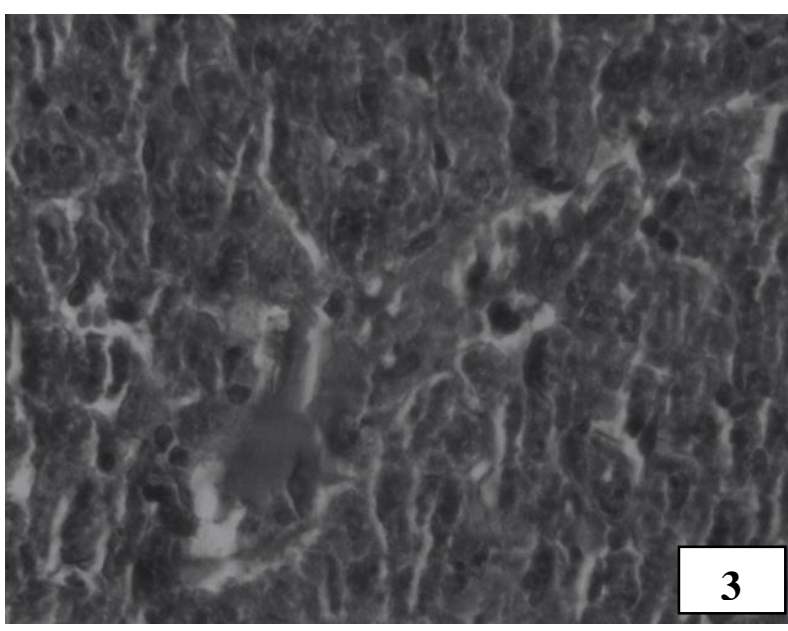

Fig. (3). AA caused necrosis of hepatic parenchyma, vacuolation, mononuclear infiltration and diffusion of Kupffer cells disturb (X400).

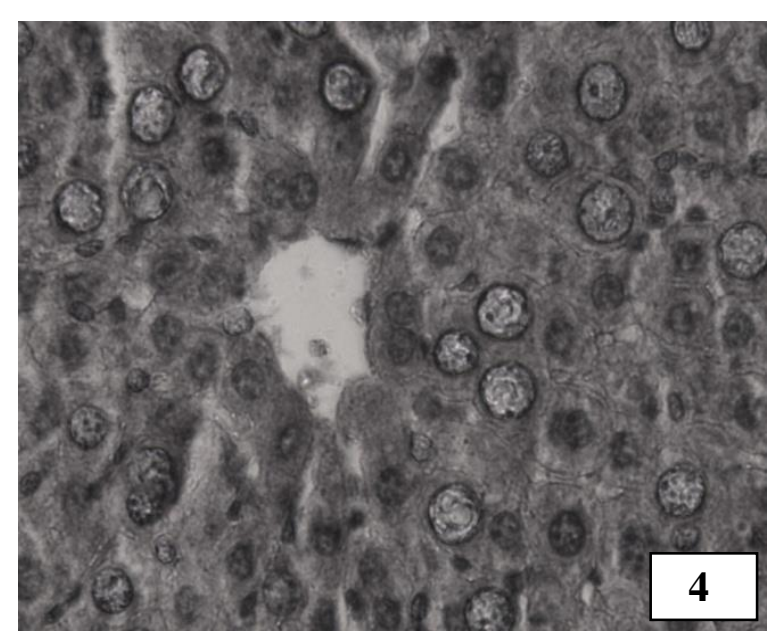

Fig. (4). Therapy with LA showed maintained cord arrangement, clear central vein, well formed nuclei vein with cuboidal hepatocytes (X400).

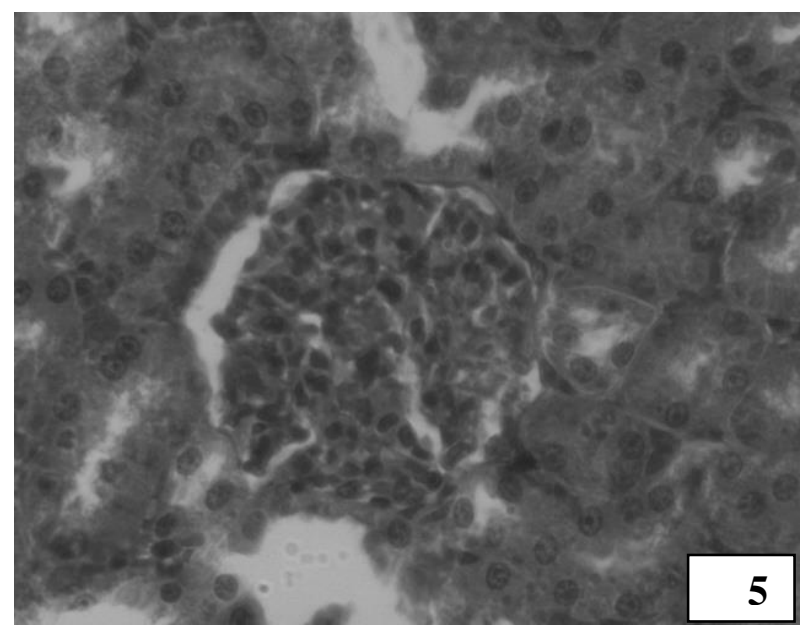

Fig. (5). AA caused degenrated glomeruli and endothelial lining and degenerated lining cells of renal tubules (X400).

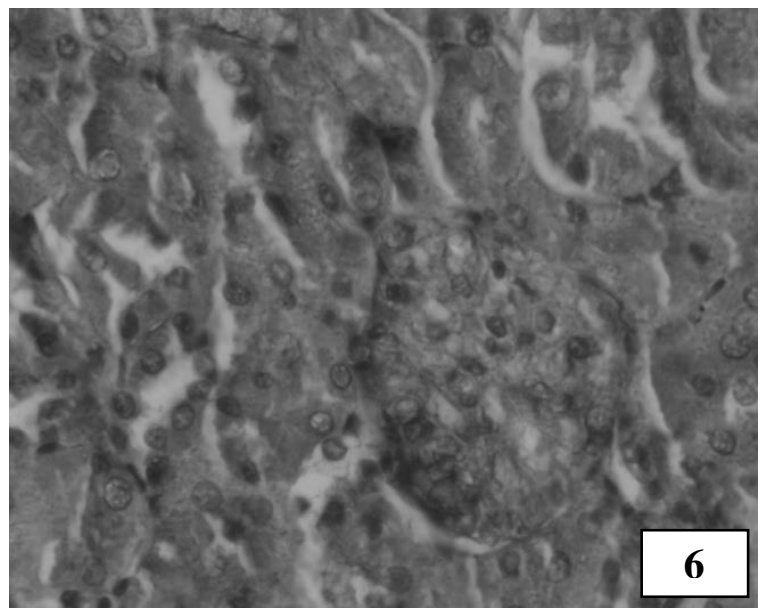

Fig. (6). LA therapy showed compact glomeruli with intact endothelial lining and maintain epithelial cells of renal tubules (X400).

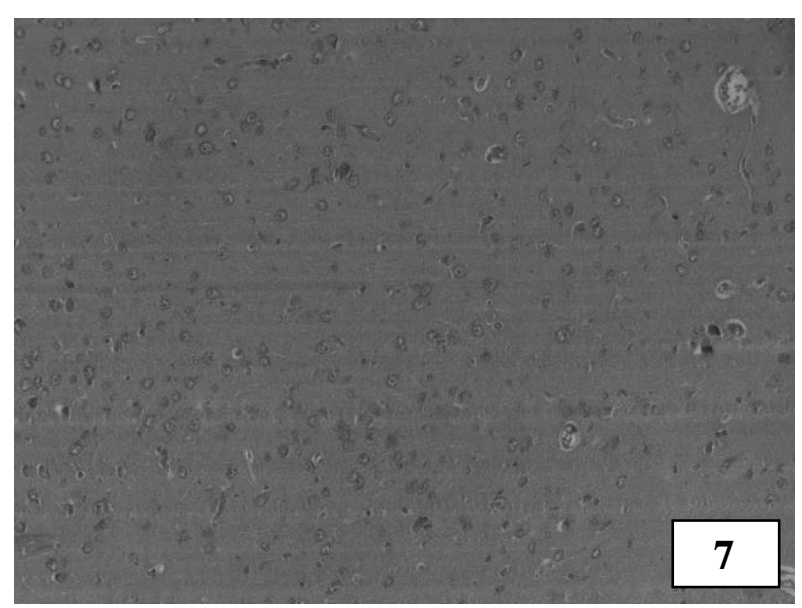

Fig. (7). AA caused vacuolization and degeneration in pyramidal and purkinje cells of cerebrum in brain (X100).

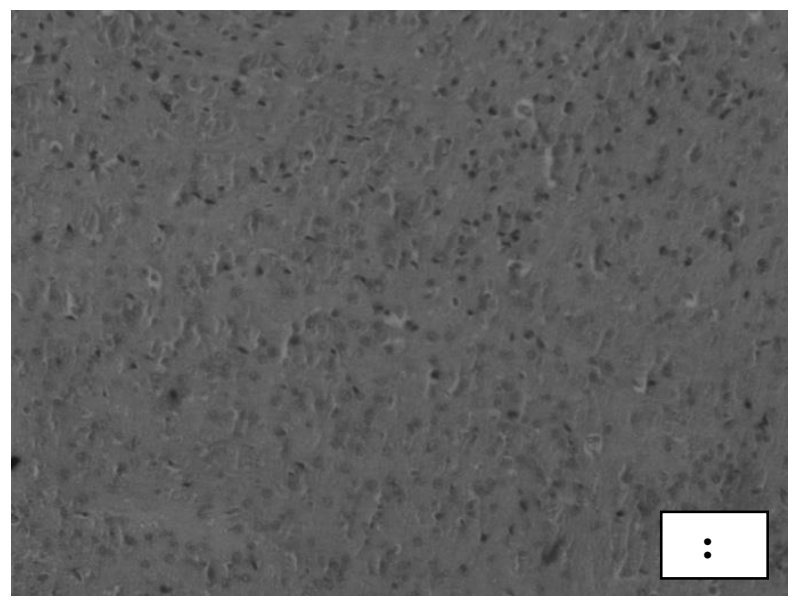

Fig. (8). LA improved purkinje and pyramidal cells in brain and reduced vacuolization, (X100).

Control rats kidney shows normal histological structure. A A administration for 10 days showed swallowed glomeruli, 
distortion in the endothelial lining of Bowman's capsule, hypertrophied epithelial cells of proximal convoluted tubule (Fig. 5). Treatment with both the higher doses of LA revealed compact glomeruli with well-formed Bowman's capsule, epithelial cells of tubules and intact endothelial lining (Fig. 6).

Brain sections of control rats showed well-formed cerebral cortex. AA induced vacuolization, degenerated pyramidal cells and reduced nerve fibres in the cerebrum (Fig. 7). Treatments of LA at $20,40 \mathrm{mg} / \mathrm{Kg}$ showed signs of recovery such as loss of vacuolization with well formedPurkinje and pyramidal cells. Both the higher doses showed an almost equal percentage of protection (Fig. 8).

\section{DISCUSSION}

Humans are exposed to acrylamide from various sources including industrial products, cigarette smoking and research laboratories [23]. Acrylamide is used in water treatment and grouting in industries and in polyacrylamide gel electrophoresis in research laboratories. AA is readily absorbed in the gastrointestinal tract after ingestion and distributed throughout the body such as the thymus, liver, heart, brain, kidneys in animals and humans. AA is metabolized via two competing pathways: the first formation of glycidamide (GA) by epoxidation reaction mediated by cytochrome $\mathrm{P} 4502 \mathrm{E} 1$ and the second via GSH conjugation [24, 25]. The CYP2E1 is involved in the conversion of AA to GA in humans and has been shown in both in vivo and in vitro and can bind in vivo with hemoglobin, serum albumins, DNA and enzymes [26, 27]. In comparison to acrylamide, glycidamide is more reactive towards proteins and DNA. It can be further hydrolyzed by an epoxide hydrolase to less reactive water-soluble 2,3-dihydroxypropionamide (glyceramide) [28, 29].

The doses of acrylamide administered to the animals in this study were very toxic that severely affected the muscular system and blood variables of the experimental animals. These parameters could also hamper the metabolism of liver, kidney and brain and physiology of many organs. However, the results of the entire experiment have been described as Mean \pm SEM of the small sample size of the experiment to show the variation among data of various groups

The Haemoglobin $(\mathrm{Hb})$ is dependent on the red blood cells population. The results of this study have shown that AA administration significantly declined $\mathrm{Hb}$ percentage in rats. This may be due to the delayed synthesis of $\mathrm{Hb}$ or haemoglobindestruction [23]. Reactive Oxygen Species (ROS) occurring at a certain level during normal metabolism is detoxified by antioxidant systems of the cell and this prevents from oxidative damage that may occur in the macromolecules of the cell. Oxidant/antioxidant balance is the relation between the level of oxidants occurring in the cell under physiologic conditions and total antioxidant capacity of the cell [30]. GSH takes charge in the antioxidant defense system of the cell. The active group of glutathione is a thiol (-SH) group in cysteine residue. It is synthesized and present in all mammalian cells. AA administration increases the generation of free oxygen radicals and decreases the GSH in all tissues of experimental animals because more GSH is used for detoxification. LA in accordance with the high GSH level within the cell decreased the GA generation and prevented the genotoxic damage based on glycidamide in a significant manner. Therefore, oxidative damage occurs in cells due to spoiling oxidant/antioxidant balance [31]. ROS generation causes oxidative deterioration of lipids resulting in lipid peroxidation. Our study found that the level of thiobarbituric acid reactive products had increased significantly in liver, kidney and brain after administrated with
AA due to the failure to detoxify the AA. Similar results noted by many researchers $[8,14,32]$.

A significant increment in AST and ALT activity was observed in the serum of AA exposed rats. These enzymes are originated from the cytoplasm. After exposure to toxicants or suffering from liver malfunctioning, these enzymes ooze into the bloodstream, thereby making cell membrane permeable. A similar finding was observed by many workers [14, 33 - 36]. Data of the current study indicate a significant decline in the albumin level after AA administration due to changes in protein metabolism in the liver or retarded protein synthesis [33]. AA also caused liver necrosis, cytoplasmic fatty vacuolation and lymphocytic infiltration [35]. Data of this investigation showed that AA cause increment in the serum creatinine and urea as compared to a control group which might be due to impairment in renal function $[33,37]$

Superoxide Dismutase (SOD) and Catalase (CAT) are antioxidant enzymes. These enzymes protect cells against ROS induced damage. Therefore, these enzymes have been used to determine oxidative stress in cells [38]. AA induced toxicity which may be due to the decrease of antioxidant defense system enzymes or induce oxidative stress with the loss of free radical scavenging activity. So, AA depletes the hepatic, renal and cerebral SOD and CAT activities thus induced oxidative stress. This suggests more utilization of these antioxidant enzymes with the consequent decline to counter the increased level of ROS by AA in liver, kidney and brain. Similar findings were observed by many authors [34, $39-41]$. LA at different doses can restore the activity of antioxidant enzymes and possibly reduce the generation of free radicals.

$\mathrm{AA}$ is a potent neurotoxic agent. It causes central and peripheral neuropathy in experimental animals. Acetylcholinesterase is presynaptic and postsynaptic components of these pathways where AChE terminates the neurotransmitter's (acetylcholine) synaptic action through catalytic hydrolysis. In the present investigation, significant down regulation in the brain Acetylcholinesterase (AChE) activity was observed which may be due to impaired function of synapses. This involves the adduction of presynaptic protein thiol groups and ultimately impaired synaptic neurotrans- mission or associated to decrease in liver GSH level. Similar results found by several authors $[32,42-44]$.

Our biochemical findings were supported by our histological observations. AA induced degeneration and necrosis of hepatic parenchyma, vacuolation, diffusion of Kupffer cells and mononuclear infiltration in the liver of rats. These results agree with the findings of other authors [44, 45]. The kidneys of AA intoxicated rats demonstrated mono cellular infiltration, degenerated epithelial cells in renal tubules which may be due to the fact that kidney excretes AA and its metabolites [45 - 47]. Previous facts suggested that AA induced neurotoxicity is associated with central and peripheral nerve terminal damage. This may be due to nerve terminals and cerebellar Purkinje cells damage [44].

Flavonoids are polyphenolic compounds act as scavengers of free radicals by $\mathrm{OH}$ groups in their molecular structure which have a property in animal and human models which is helpful for preventing a number of chronic diseases and reduced toxicities [48 - 51]. PUFA (Polyunsaturated fatty acids) are hydrocarbon chains with two double bonds and lack several hydrogen atoms which are essential for the healthrelated benefits and proper functioning of the human body [52, 53]. Their deficiency leads to growth retardation, infertility, skin problem, the function of the mitochondria and kidney regeneration [53]. It maintains the cell membranes and control metabolism of cells which strengthen the body's natural 
defenses along with suppressing inflammation [54]. It is noteworthy that, in the AA supplemented with LA, enhanced hepatic, renal and cerebral antioxidant enzyme activities when compared with the AA administered group. As a result, LA may have a protective role against ROS mediated damage, thereby causes prevention against lipid peroxidation. Thus, it seems quite reasonable to say that LA was effective for preventing hepatic, renal and cerebral damage which may be due to its free radical scavenging activity. These results provide further evidence for the antioxidant properties of dietary flavonoids as chemopreventive agents in AA toxicity as it has a hydroxyl group.

Apart from the animal studies, toxic consequences of acrylamide on human beings or its presence in human tissues samples and junk foods may also be investigated in the future to correlate the multi-organ dysfunction and acrylamide exposure. In general, disadvantages for antioxidant supplementation are scanty and excess antioxidant supplements may cause metabolic disorders. However, lesser doses of antioxidant have been used and evaluated in this studyFurther, investigations are also necessary to evaluate the therapeutic potential and mechanism of LA for the protection against AA toxicity.

\section{ETHICS APPROVAL AND CONSENT TO PARTICIPATE}

The experimentation on animals had been conducted with prior approval of Institutional Ethics Committee (No. IAEC/ JU/2012/04 and date of approval 16th May 2012).

\section{HUMAN AND ANIMAL RIGHTS}

No humans were used for studies that are the basis of this research. All applicable national and institutional (CPCSEA) guidelines for the care and use of animal were followed.

\section{CONSENT FOR PUBLICATION}

Not applicable.

\section{AVAILABILITY OF DATA AND MATERIALS}

Not applicable.

\section{FUNDING}

The study was financially supported by the Department of Science and Technology (DST), New Delhi (SR/WOSA/LS-389/2012).

\section{CONFLICT OF INTERESTS}

The authors declare no conflict of interest, financial or otherwise.

\section{ACKNOWLEDGEMENTS}

Declared none.

\section{REFERENCES}

[1] Fukumitsu S. A-Linolenic acid suppresses cholesterol and triacylglycerol biosynthesis pathway by suppressing SREBP-2, SREBP-1a and -1c expression. Cytotechnology 2013; 65: 899-907. [http://dx.doi.org/10.1007/s10616-012-9510-x] [PMID: 23138267]

[2] Burdge GC. Metabolism of alpha-linolenic acid in humans. Prostaglandins Leukot Essent Fatty Acids 2006; 75(3): 161-8. [http://dx.doi.org/10.1016/j.plefa.2006.05.013] [PMID: 16828546]
[3] Blondeau N, Lipsky RH, Bourourou M, Duncan MW, Gorelick PB, Marini AM. Alpha-linolenic acid: An omega-3 fatty acid with neuroprotective properties-ready for use in the stroke clinic? BioMed Res Int 2015; 2015519830

[http://dx.doi.org/10.1155/2015/519830] [PMID: 25789320]

[4] Carballeira NM. New advances in fatty acids as antimalarial, antimycobacterial and antifungal agents. Prog Lipid Res 2008; 47(1): 50-61.

[http://dx.doi.org/10.1016/j.plipres.2007.10.002] [PMID: 18023422]

[5] Das UN. Can essential fatty acids reduce the burden of disease(s)? Lipids Health Dis 2008; 7: 9.

[http://dx.doi.org/10.1186/1476-511X-7-9] [PMID: 18348729]

[6] Melariri P, Campbell W, Etusim P, Smith P. In vitro and in Vivo Antimalarial Activity of Linolenic and Linoleic Acids and their Methyl Esters. Adv Studies Biol 2012; 4(7): 333-49.

[7] Rawi SM, Marie MAS, Fahmy SR, El-Abied SA. Hazardous effects of acrylamide on immature male and female rats. Afr J Pharm Pharmacol 2012; 6(18): 1367-86.

[8] Erdemli ME, Turkoz Y, Altinoz E, Elibol E, Dogan Z. Investigation of the effects of acrylamide applied during pregnancy on fetal brain development in rats and protective role of the vitamin E. Hum Exp Toxicol 2016; 35(12): 1337-44.

[http://dx.doi.org/10.1177/0960327116632049] [PMID: 26916244]

[9] Kahkeshani N, Saeidnia S, Abdollahi M. Role of antioxidants and phytochemicals on acrylamide mitigation from food and reducing its toxicity. J Food Sci Technol 2015; 52(6): 3169-86.

[PMID: 26028700]

[10] Tareke E, Heinze TM, Gamboa da Costa G, Ali S. Acrylamide formed at physiological temperature as a result of asparagine oxidation. J Agric Food Chem 2009; 57(20): 9730-3.

[http://dx.doi.org/10.1021/jf901812u] [PMID: 19772296]

[11] Rajeh NA, Al-Dhaheri NM. Antioxidant effect of vitamin E and 5aminosalicylic acid on acrylamide induced kidney injury in rats. Saudi Med J 2017; 38(2): 132-7.

[http://dx.doi.org/10.15537/smj.2017.2.16049] [PMID: 28133684]

[12] Wang ET, Chen DY, Liu HY, Yan HY, Yuan Y. Protective effect of allicin against glycidamide-induced toxicity in male and female mice. Gen Physiol Biophys 2015; 34(2): 177-87.

[http://dx.doi.org/10.4149/gpb_2014038] [PMID: 25730897]

[13] Dybing E, Farmer PB, Andersen M, et al. Human exposure and internal dose assessments of acrylamide in food. Food Chem Toxicol 2005; 43(3): 365-410.

[http://dx.doi.org/10.1016/j.fct.2004.11.004] [PMID: 15680675]

[14] Mehri S, Abnous K, Mousavi SH, Shariaty VM, Hosseinzadeh H. Neuroprotective effect of crocin on acrylamide-induced cytotoxicity in PC12 cells. Cell Mol Neurobiol 2012; 32(2): 227-35.

[http://dx.doi.org/10.1007/s10571-011-9752-8] [PMID: 21901509]

[15] Riley V. Adaptation of orbital bleeding technic to rapid serial blood studies. Proc Soc Exp Biol Med 1960; 104: 751-4.

[http://dx.doi.org/10.3181/00379727-104-25975] [PMID: 13741689]

[16] Reitman S, Frankel S. A colorimetric method for the determination of serum glutamic oxalacetic and glutamic pyruvic transaminases. Am J Clin Pathol 1957; 28(1): 56-63.

[http://dx.doi.org/10.1093/ajcp/28.1.56] [PMID: 13458125]

[17] Ellman GL, Courthey KD, Anders V, Feather S. Determination of acetyl cholinesterase. Biochem Pharmacol 1961; 7: 88-95.

[http://dx.doi.org/10.1016/0006-2952(61)90145-9] [PMID: 13726518]

[18] Sharma SK, Krishna Murti CR. Production of lipid peroxides by brain. J Neurochem 1968; 15(2): 147-9.

[http://dx.doi.org/10.1111/j.1471-4159.1968.tb06187.x] [PMID: 5637724]

[19] Brehe JE, Burch HB. Enzymatic assay for glutathione. Anal Biochem 1976; 74(1): 189-97.

[http://dx.doi.org/10.1016/0003-2697(76)90323-7] [PMID: 962073]

[20] Aebi H. Catalase in vitro. Methods Enzymol 1984; 105: 121-6. [http://dx.doi.org/10.1016/S0076-6879(84)05016-3] [PMID: 6727660]

[21] Misra HP, Fridovich I. The role of superoxide anion in the autoxidation of epinephrine and a simple assay for superoxide dismutase. J Biol Chem 1972; 247(10): 3170-5.

[PMID: 4623845]

[22] Snedecor GW, Cochran WG. Statistical method. 8th ed. Ames, Iowa: Affiliated East-West Press 1994.

[23] Bergmark E. Hemoglobin adducts of acrylamide and acrylonitrile in laboratory workers, smokers and nonsmokers. Chem Res Toxicol 1997; 10(1): 78-84.

[http://dx.doi.org/10.1021/tx960113p] [PMID: 9074806]

[24] Friedman M. Chemistry, biochemistry, and safety of acrylamide. A 
review. J Agric Food Chem 2003; 51(16): 4504-26. [http://dx.doi.org/10.1021/jf030204+] [PMID: 14705871]

[25] Zhang Y, Wang Q, Cheng J, Zhang J, Xu J, Ren Y. Comprehensive profiling of mercapturic acid metabolites from dietary acrylamide as short-term exposure biomarkers for evaluation of toxicokinetics in rats and daily internal exposure in humans using isotope dilution ultra-high performance liquid chromatography tandem mass spectrometry. Anal Chim Acta 2015; 894(894): 54-64.

[http://dx.doi.org/10.1016/j.aca.2015.08.033] [PMID: 26423628]

[26] Doroshyenko O, Fuhr U, Kunz D, et al. In vivo role of cytochrome P450 2E1 and glutathione-S-transferase activity for acrylamide toxicokinetics in humans. Cancer Epidemiol Biomarkers Prev 2009; 18(2): 433-43.

[http://dx.doi.org/10.1158/1055-9965.EPI-08-0832]

[PMID: 19190172]

[27] Shipp A, Lawrence G, Gentry R, et al. Acrylamide: Review of toxicity data and dose-response analyses for cancer and noncancer effects. Crit Rev Toxicol 2006; 36(6-7): 481-608.

[http://dx.doi.org/10.1080/10408440600851377] [PMID: 16973444]

[28] Dearfield KL, Douglas GR, Ehling UH, Moore MM, Sega GA, Brusick DJ. Acrylamide: A review of its genotoxicity and an assessment of heritable genetic risk. Mutat Res 1995; 330(1-2): 71-99. [http://dx.doi.org/10.1016/0027-5107(95)00037-J] [PMID: 7623872]

[29] Sumner SC, Fennell TR, Moore TA, Chanas B, Gonzalez F, Ghanayem BI. Role of cytochrome P450 2E1 in the metabolism of acrylamide and acrylonitrile in mice. Chem Res Toxicol 1999; 12(11): 1110-6.

[http://dx.doi.org/10.1021/tx990040k] [PMID: 10563837]

[30] Cheeseman KH, Slater TF. An introduction to free radical biochemistry. Br Med Bull 1993; 49(3): 481-93.

[http://dx.doi.org/10.1093/oxfordjournals.bmb.a072625] [PMID: 8221017]

[31] Puppel N, Tjaden Z, Fueller F, Marko D. DNA strand breaking capacity of acrylamide and glycidamide in mammalian cells. Mutat Res 2005; 580(1-2): 71-80

[http://dx.doi.org/10.1016/j.mrgentox.2004.11.009] [PMID: 15668109]

[32] Lebda MA, Gad SB, Rashed RR. The effect of lipoic acid on acrylamide-induced neuropathy in rats with reference to biochemical, hematological, and behavioral alterations. Pharm Biol 2015; 53(8): 1207-13.

[http://dx.doi.org/10.3109/13880209.2014.970288] [PMID: 25853975]

[33] Abdel-Daim MM. AbdEldaim, M.A., Hassan, A.G.;Trigonellafoenumgraecum ameliorates acrylamide-induced toxicity in rats: Roles of oxidative stress, proinflammatory cytokines, and DNA damage. Biochem Cell Biol 2015; 93(3): 192-8.

[http://dx.doi.org/10.1139/bcb-2014-0122] [PMID: 25607344]

[34] Allam A, El-Gareeb A, Ajarem J, Abdul-Hamid M, El-Bakry A. Effect of acrylamide on the development of medulla oblongata in albino rat: Biochemical and morphological studies. Afr J Pharm Pharmacol 2013; 7(20): 1320-31.

[35] Lal R, Arora M, Sharma A. Acrylamide caused hematotoxicity on musmusculus through gavage. Ind. J Fund Appl. Life Sci 2011; 1(4): $330-4$.

[36] Uboh FE, Ebong PE, Eka OU, Eyong EU, Akpanabiatu MI. Effect of inhalation exposure to kerosene and petrol fumes on some anaemiadiagnostic indices in rats. Glob J Environ Sci 2005; 3: 59-63.

[http://dx.doi.org/10.4314/gjes.v4i1.2442]

[37] Shelly M. Calder. Christchurch, New Zealand: Transcript Records of New Zealand High Court 1996.

[38] Liu CM, Ma JQ, Lou Y. Chronic administration of troxerutin protects mouse kidney against D-galactose-induced oxidative DNA damage. Food Chem Toxicol 2010; 48(10): 2809-17 [http://dx.doi.org/10.1016/j.fct.2010.07.011] [PMID: 20633594]

[39] Mohamed Sadek K. Antioxidant and immunostimulant effect of carica papaya linn. Aqueous extract in acrylamide intoxicated rats. Acta Inform Med 2012; 20(3): 180-5

[http://dx.doi.org/10.5455/aim.2012.20.180-185] [PMID: 23322975]

[40] Bandhopadhay U, Das D, Banerjee KR. Reactive oxygen species: Oxidative damage and pathogenesis. Curr Sci 1999; 77: 658-65.

[41] Tabatabaie T, Floyd RA. Susceptibility of glutathione peroxidase and glutathione reductase to oxidative damage and the protective effect of spin trapping agents. Arch Biochem Biophys 1994; 314(1): 112-9. [http://dx.doi.org/10.1006/abbi.1994.1418] [PMID: 7944382]

[42] Uthra C, Shrivastava S, Jaswal A, Sinha N, Reshi MS, Shukla S. Therapeutic potential of quercetin against acrylamide induced toxicity in rats. Biomed Pharmacother 2017; 86: 705-14.

[http://dx.doi.org/10.1016/j.biopha.2016.12.065] [PMID: 28039850]

[43] Zhu YJ, Zeng T, Zhu YB, et al. Effects of acrylamide on the nervous tissue antioxidant system and sciatic nerve electrophysiology in the rat. Neurochem Res 2008; 33(11): 2310-7.

[http://dx.doi.org/10.1007/s11064-008-9730-9] [PMID: 18470611]

[44] LoPachin RM, Schwarcz AI, Gaughan CL, Mansukhani S, Das S. In vivo and in vitro effects of acrylamide on synaptosomal neurotransmitter uptake and release. Neurotoxicology 2004; 25(3): 349-63.

[http://dx.doi.org/10.1016/S0161-813X(03)00149-9] [PMID: 15019298]

[45] Mahmood SAF, Amin KAM, Salih SFM. Effect of acrylamide on liver and kidneys in albino wistar rats. Int J Curr Microbiol Appl Sci 2015; 4(5): 434-44.

[46] Mansour MK, Ibrahim EM, El-Kholy MM, El-Madawy SA Antioxidant and histopathological effect of catechin and neem leaves extract in acrylamide toxicity of rats. Egypt J Comp ClinPathol 2008; 21: 290-313.

[47] Jabbar SA. Study the effect of acrylamide on some physiological and histological properties of rabbits kidney who drenched with Flavonoids that extracted from grape seeds. J Kerbala Univ 2011; 9: 209-18.

[48] Motamedshariaty S V. Effects of rutin on acrylamide-induced neurotoxicity. Daru 2014; 22(1): 1-9.

[49] Shinomol GK, Raghunath N, Bharath MM, Muralidhara M. Prophylaxis with Bacopa monnieri attenuates acrylamide induced neurotoxicity and oxidative damage via elevated antioxidant function. Cent Nerv Syst Agents Med Chem 2013; 13(1): 3-12.

[http://dx.doi.org/10.2174/1871524911313010003] [PMID: 23092408]

[50] Mehri S, Abnous K, Khooei A, Mousavi SH, Shariaty VM, Hosseinzadeh H. Crocin reduced acrylamide-induced neurotoxicity in Wistar rat through inhibition of oxidative stress. Iran J Basic Med Sci 2015; 18(9): 902-8 [PMID: 26523222]

[51] Chirumbolo S. The role of quercetin, flavonols and flavones in modulating inflammatory cell function. Inflamm Allergy Drug Targets 2010; 9(4): 263-85.

[http://dx.doi.org/10.2174/187152810793358741] [PMID: 20887269]

[52] Das UN. Essential fatty acids - a review. Curr Pharm Biotechnol 2006; 7(6): 467-82.

[http://dx.doi.org/10.2174/138920106779116856] [PMID: 17168664]

[53] Dobryniewski J, Szajda SD, Waszkiewicz N, Zwierz K. Biology of essential fatty acids (EFA). Przegl Lek 2007; 64(2): 91-9. [PMID: 17892040]

[54] Peyrat-Maillard MN, Cuvelier ME, Berset C. Antioxidant activity of phenolic compounds in 2,2'-azobis (2-amidinopropane) dihydrochloride (AAPH)-induced oxidation: Synergistic and antagonistic effects. J Am Oil Chem Soc 2003; 80(10): 1007-12. [http://dx.doi.org/10.1007/s11746-003-0812-z]

(C) 2019 Shrivastava et al.

This is an open access article distributed under the terms of the Creative Commons Attribution 4.0 International Public License (CC-BY 4.0), a copy of which is available at: (https://creativecommons.org/licenses/by/4.0/legalcode). This license permits unrestricted use, distribution, and reproduction in any medium, provided the original author and source are credited. 